\title{
Dioxygen Binding by Cobalt(II) Complexes of 8,8'-bis(aminomethyl)-2,2'-biquinoline
}

\author{
Muhammad S. Khan ${ }^{1 *}$, Nawal K. Al-Rasbi ${ }^{1}$ and Edwin C.Constable ${ }^{2}$ \\ ${ }^{1}$ Department of Chemistry, College of Science, Sultan Qaboos University, P.O. Box: 36, PC \\ 123, Al-Khod, Muscat, Sultanate of Oman, ${ }^{2}$ Department of Chemistry, University of Basel,

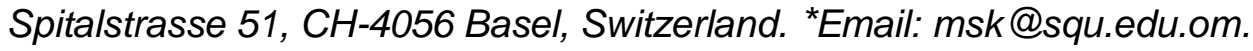

\begin{abstract}
A new series of $\mathrm{Co}(\mathrm{II})$ complexes of the type $\mathrm{CoLX}_{2}$, where $\mathrm{L}$ is a tetra-dentate ligand 8,8'bis(aminomethyl)-2,2'-biquinoline and $\mathrm{X}=\mathrm{SCN}^{-}, \mathrm{BF}_{4}^{-}, \mathrm{I}^{-}$or $\mathrm{NO}_{3}{ }^{-}$, have been synthesized and characterized. The complexes have magnetic moments in the range typical of a low-spin $\mathrm{d}^{7} \mathrm{Co}$ (II) center. The interaction of these Co(II) complexes with dioxygen was studied by E.S.R. spectroscopy. A dicobalt(III) peroxo-bridged complex was formed in DMF solution, associated with the formation of an E.S.R.-silent solution compatible with the formation of low-spin $\mathrm{d}^{6} \mathrm{Co}$ (III) species. Similar behavior was also observed for the interaction of these $\mathrm{Co}(\mathrm{II})$ complexes with dioxygen in the presence of ancillary ligands such as pyridine and 2methylimidazole. The dioxygen complexes proved successful as oxygen carrier oxidation catalysts for tripehnylphosphine and 2,6-bis $\left({ }^{t}\right.$-butyl $)$ phenol.
\end{abstract}

Keywords: Biquinoline; Cobalt(II); Dioxygen interaction; E.S.R.

$$
\text { ارتباط الأكسجين مع مركبات الكوبالت من 8,8'-ثنائي أمينوميثيل-2,2'ثثائي كوينولين }
$$$$
\text { محمد س. خان، نوال خ. الراسبية و ادوين س. كونيستابل }
$$

ملخص: نم تكوين سلسلة جديدة لمركبات الكوبالت بالصيغة

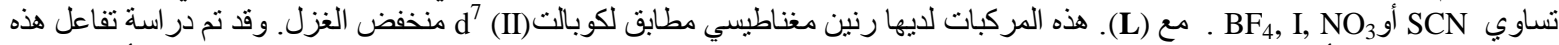

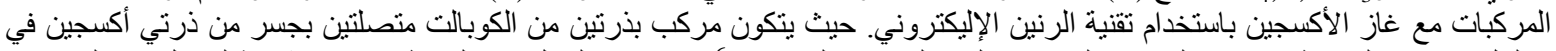

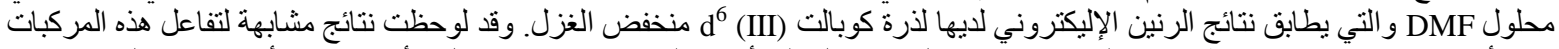

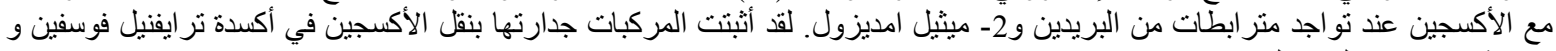
2,6 - ثنائي ت بيونيل فينول.

\section{Introduction}

$$
\text { مفتاح الكلمات: كوينولين ، كوبالت، تفاعل مع الأكسجين ، الرنين الإليكتروني. }
$$

$\mathbf{T}$ The transport of dioxygen by reversible binding to transition metal complexes plays an essential role in the life processes of multicellular organisms. In recent years our understanding of the molecular basis of in vivo oxygen binding and transport has been aided by a wide range of in vitro studies. Numerous simple chemical systems have been developed, which exhibit dioxygen binding that is reversible to variable degrees [1-4]. Although the common biological transport systems contain iron at the dioxygen binding site, coordination compounds of cobalt have proved to be valuable models for understanding and controlling the types of metaldioxygen interaction that may occur [5,6]. The nature of dioxygen binding by cobalt(II) complexes has been shown to depend crucially upon the nature of the ligands coordinated to the metal [7]. Limiting behavior is observed in the formation of 1:1 complexes containing cobalt(III) superoxides and 1:2 complexes with peroxidebridged dicobalt(III) species. This behaviour is typified by complexes such as $[\mathrm{Co}($ salen $)]\left(\mathrm{H}_{2} \mathrm{salen}=\mathrm{H}_{2} \mathrm{~L}^{1}\right)$ and [Co(acacen) $]\left(\mathrm{H}_{2}\right.$ acen $\left.=\mathrm{H}_{2} \mathrm{~L}^{2}\right)$ or $[\mathrm{Co}($ bzacen $)]\left(\mathrm{H}_{2}\right.$ bzacen $\left.=\mathrm{H}_{2} \mathrm{~L}^{3}\right)$. In the solid state $[\mathrm{Co}($ salen $)]$ reversibly absorbs dioxygen at a ratio of 2:1 to give a compound in which the dioxygen bridges the cobalt atoms of two coplanar complex molecules; i.e. approaching the peroxide-bridged dicobalt(III) structure [8,9]. In N,Ndimethylformamide (DMF) solution, the complex also reacts reversibly with dioxygen to form a peroxo-bridged dicobalt(III) complex [10]. In this case, the cobalt(III) centers are six-coordinate and the remaining axial site is occupied by a DMF ligand. In contrast to this, the complexes $[\mathrm{Co}($ acacen $)]$ or $[\mathrm{Co}($ bzacen $)]$ react with dioxygen 
only in the presence of a strong axial donor such as pyridine, to yield six-coordinate cobalt(III) superoxide complexes $\left[\mathrm{Co}(\right.$ acacen $\left.)(\mathrm{py})\left(\mathrm{O}_{2}\right)\right]$ or $\left(\mathrm{Co}(\right.$ bzacen $\left.)(\mathrm{py})\left(\mathrm{O}_{2}\right)\right]$ [11-14]. Complexes of neutral macrocyclic ligands are also known to react reversibly with dioxygen. We wish to report in this paper the synthesis and characterization of some cobalt complexes of the tetra-dentate ligand 8,8'-bis(aminomethyl)-2,2'-biquinoline (L), and also to describe the interactions of these complexes with dioxygen in a variety of solvents.

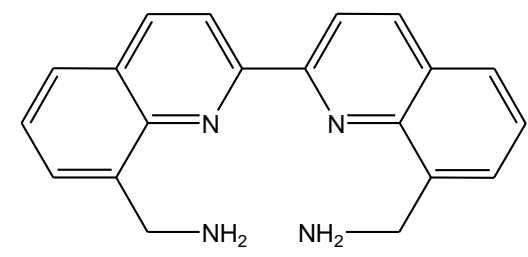

$\mathrm{L}$

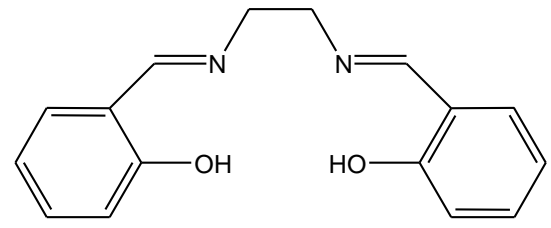

$\mathrm{H}_{2} \mathrm{~L}^{1}$

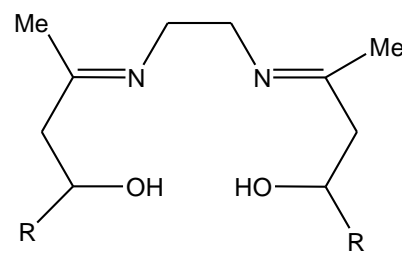

$\mathrm{H}_{2} \mathrm{~L}^{2} \quad \mathrm{R}=\mathrm{Me}$

$\mathrm{H}_{2} \mathrm{~L}^{3} \quad \mathrm{R}=\mathrm{Ph}$

Chart 1. Ligands $\mathbf{L}$ used in this work and some related ligands $\mathbf{H}_{2} \mathbf{L}^{1-3}$.

\section{Experimental}

Infra-red spectra were recorded in compressed KBr pellet on Perkin Elmer FT 910 or Perkin Elmer 983 spectrophotometers. Mass spectra were recorded on a Kratos MS 30 mass spectrometer. Electronic spectra were recorded on a Pye-Unicam PU 8800 spectrophotometer. E.S.R. spectra were recorded using a Varian E 109 spectrometer; g values were determined by reference to a 2,2-diphenyl-1-picrylhydrazyl hydrate standard ( $g=$ 2.0036). Magnetic susceptibilities were measured using a Johnson Matthey susceptibility balance calibrated using copper sulphate pentahydrate and mercury cobalt thiocyanate. The ligand 8,8'-bis(aminomethyl)-2,2'biquinoline (L) was prepared as reported in the literature [15]. All chemicals, reagents, cobalt salts and solvents were purchased from Sigma Aldrich and used without further purification.

\section{Synthesis of $\left\{\mathrm{CoL}(\mathrm{SCN})_{2}\right\}$}

A degassed solution of $\mathbf{L}(0.05 \mathrm{~g}, 0.16 \mathrm{mmol})$ in methanol $(5 \mathrm{~mL})$ was added to a boiling solution of $\mathrm{Co}(\mathrm{SCN})_{2}(0.03 \mathrm{~g}, 0.17 \mathrm{mmol})$ in methanol $(25 \mathrm{~mL})$ maintained under an atmosphere of dinitrogen. The resultant solution was heated to reflux for $2 \mathrm{~h}$, and allowed to cool. The fine green solid which precipitated was collected by filtration and dried to yield $\left\{\mathrm{CoL}(\mathrm{SCN})_{2}\right\}(0.055 \mathrm{~g}, 70 \%)$. The nitrate and the iodide derivatives were prepared in an analogous manner from the appropriate cobalt salts.

\section{Synthesis of $\left\{\mathrm{CoL}\left(\mathrm{BF}_{4}\right)_{2} \cdot \mathrm{H}_{2} \mathrm{O}\right\}$}

To a degassed solution of $\mathbf{L}(0.40 \mathrm{~g}, 1.27 \mathrm{mmol})$ in methanol $(200 \mathrm{~mL})$ maintained under an atmosphere of dinitrogen was added a degassed solution of $\mathrm{Co}\left(\mathrm{BF}_{4}\right)_{2} \cdot 6 \mathrm{H}_{2} \mathrm{O}(0.33 \mathrm{~g}, 1.3 \mathrm{mmol})$ in methanol $(5 \mathrm{~mL})$. The resultant deep purple solution was heated to reflux under a dinitrogen atmosphere for $2 \mathrm{~h}$, and allowed to cool. The solution was then concentrated under reduced pressure and allowed to cool, when a purple-red complex was obtained $(0.48 \mathrm{~g}, 70 \%)$. The solid was reasonably stable in air, but was routinely stored under dinitrogen. Recrystallization by the diffusion of diethyl ether vapor into an acetonitrile solution of the complex yielded fine red needles, which crumbled to a red powder upon removal of the solvent mixture of recrystallization.

\section{Synthesis of $\left\{\mathrm{LCo}\left(\mu-\mathrm{O}_{2}\right) \mathrm{CoLI}_{4}\right\}$}

Dioxygen was bubbled through a solution of $\left(\mathrm{CoLI}_{2} \cdot \mathrm{H}_{2} \mathrm{O}\right)(0.20 \mathrm{~g}, 0.32 \mathrm{mmol})$ in boiling methanol $(700$ $\mathrm{mL}$ ) for $15 \mathrm{~min}$. The resultant red-brown solution was filtered, and the filtrate concentrated by boiling in air to about $50 \mathrm{~mL}$ volume. Upon cooling, a red-brown microcrystalline solid precipitated, which was collected by filtration and dried in air to yield $\left\{\mathrm{LCo}\left(\mu-\mathrm{O}_{2}\right) \mathrm{CoLI}_{4}\right) \cdot 6 \mathrm{H}_{2} \mathrm{O}(0.107 \mathrm{~g}, 55 \%)$. 


\section{DIOXYGEN BINDING BY COBALT(II) COMPLEXES}

\section{Typical conditions for the oxidation of triphenylphosphine}

A suspension of $\left\{\mathrm{CoLI}_{2} \cdot \mathrm{H}_{2} \mathrm{O}\right\}(0.05 \mathrm{~g}, 0.08 \mathrm{mmol})$ in methanol $(70 \mathrm{~mL})$ was treated with dioxygen to yield a redbrown solution. A similar flask was prepared containing only methanol $(70 \mathrm{~mL})$. Each of these flasks had triphenylphosphine $\left(0.1 \mathrm{~g}, 0.38 \mathrm{mmol}\right.$, oxide free) added. These solutions were maintained at $25{ }^{\circ} \mathrm{C}$ and dioxygen was bubbled through each for $4 \mathrm{~h}$. After this period TLC analysis indicated that in the solution containing the metal complex, the triphenylphosphine had been completely converted to triphenylphosphine oxide, whereas there were no detectable amounts of triphenylphosphine oxide in the control reaction. The solution containing the cobalt complex was evaporated to dryness and the residue extracted with diethyl ether $(2 \mathrm{x} 50 \mathrm{~mL})$. The ether extract was then evaporated to dryness to yield triphenylphosphine oxide $(0.10 \mathrm{~g}, 95 \%)$ as a white crystalline solid which was shown to be pure by infrared, ${ }^{1} \mathrm{H}$ and ${ }^{31} \mathrm{P}$ NMR spectroscopy.

\section{Typical conditions for the oxidation of 2,6-bis $\left({ }^{t}\right.$-butyl)phenol}

2,6-Bis ( ${ }^{t}$-butyl)phenol $(0.3 \mathrm{~g}, 1.45 \mathrm{mmol})$ was added to a solution of $\left\{\mathrm{CoL}\left(\mathrm{BF}_{4}\right)_{2} \cdot \mathrm{H}_{2} \mathrm{O}\right)(0.05 \mathrm{~g}, 0.09 \mathrm{mmol})$ in DMF $(25 \mathrm{~mL})$. Dioxygen was then bubbled through the solution for $12 \mathrm{~h}$, after which period the red crystalline product was collected by filtration. These red needles were characterized as pure tetra $\left({ }^{\mathrm{t}}\right.$-butyl $)$ diphenoquinone by infrared and ${ }^{1} \mathrm{H}$ NMR spectroscopy $(0.10 \mathrm{~g}, 30 \%)$. The filtrate was poured into water $(10 \mathrm{~mL})$ and the dark coloured solution extracted with diethyl ether $(3 \times 50 \mathrm{~mL})$. The ether extract was dried $\left(\mathrm{MgSO}_{4}\right)$ and evaporated to dryness in vacuum. The residue was dissolved in the minimum volume of chloroform and chromatographed on a silica column $\left(\mathrm{CHCl}_{3}\right.$ eluant) to yield pure 2,6-bis $\left({ }^{t}\right.$-butyl)quinone $(0.185 \mathrm{~g}, 60 \%)$. A control experiment in which no cobalt complex was present showed very small quantities of oxidation product.

\section{Results and discussion}

We have previously described the preparation of the tetradentate ligand 8,8'- bis(aminomethyl)-2,2'-biquinoline (L) which was intended as a precursor to macrocyclic ligands containing a 2,2'-biquinolyl moiety [15]. In the course of our investigations into the coordination chemistry of this ligand we noticed that the cobalt(II) complexes underwent partially reversible changes upon interaction with dioxygen.

The reaction of cobalt(II) salts with $\mathbf{L}$ in methanol in the absence of dixoygen resulted in the formation of colored solutions containing complexes with a 1:1 metal:ligand stoichiometry. These complexes are either green $\left(\mathrm{I}^{-}, \mathrm{SCN}^{-}\right.$or $\left.\mathrm{NO}_{3}{ }^{-}\right)$or red-purple $\left(\mathrm{BF}_{4}{ }^{-}\right)$, depending upon the presence and nature of coordinating anions. In general, the complexes were obtained as monohydrated species. The compounds obtained from cobalt(II) iodide or cobalt(II) nitrate both exhibited room temperature magnetic moment close to $2.2 \mathrm{~B} . \mathrm{M}$ in the solid state, while the thiocyanate showed a moment of 2.51 B.M. and the tetrafluoroborate exhibited a room temperature solid state moment of 3.12 B.M. In each case the magnetic moments were considerably below the spin-only value expected for a high-spin $\mathrm{d}^{7}$ ion (3.87 B.M.) and significantly below the usual values observed for high-spin cobalt(II) complexes (4.5 - 5.3 B.M. in various geometries), which exhibit large orbital contributions at room temperature.

Table 1. Elemental analysis and magnetic moments for Co(II) complexes.

\begin{tabular}{|c|c|c|c|c|c|}
\hline Compound & $\begin{array}{l}\text { Calc } \\
\mathrm{C} \quad \mathrm{H}\end{array}$ & $\mathbf{N}$ & $\begin{array}{l}\text { Found } \\
\text { C H }\end{array}$ & $\mathbf{N}$ & $\begin{array}{l}\mu_{\text {eff }} \\
\text { (B.M.) }\end{array}$ \\
\hline$\left\{\mathrm{CoL}\left(\mathrm{BF}_{4}\right)_{2} \cdot \mathrm{H}_{2} \mathrm{O}\right\}$ & 42.63 & 9.6 & 42.93 & 9.8 & 3.12 \\
\hline$\left\{\mathrm{CoL}\left(\mathrm{NO}_{3}\right)_{2} \cdot \mathrm{H}_{2} \mathrm{O}\right\}$ & 46.63 & 16.3 & 46.63 & 15.5 & 2.25 \\
\hline$\left\{\mathrm{CoLI}_{2} \cdot \mathrm{H}_{2} \mathrm{O}\right\}$ & 37.23 & 8.4 & 37.03 & 8.1 & 2.23 \\
\hline$\left\{\mathrm{CoL}(\mathrm{SCN})_{2}\right\}$ & $\begin{array}{ll}54.0 & 3 \\
\end{array}$ & 17.2 & 53.93 & 17.0 & 2.51 \\
\hline$\left\{\mathrm{Co}_{2} \mathrm{~L}_{2}\left(\mathrm{O}_{2}\right) \mathrm{I}_{4} \cdot 6 \mathrm{H}_{2} \mathrm{O}\right\}$ & 34.43. & 8.0 & 34.13 & 7.8 & 0 \\
\hline
\end{tabular}

Low-spin complexes of cobalt(II) commonly exhibit square planar four coordinate or square pyramidal five coordinate geometries, and the magnetic moments for these compounds are typically in the range 2.0 - 3.0 B.M. at room temperature, although a very wide range of values have been reported $[8,14,15]$. We have previously demonstrated that the ligand $\mathrm{L}$ may form six-coordinate $\left(\left[\mathrm{MnLC1}_{2}\right]\right)$ and five-coordinate $([\mathrm{CuLCI}] \mathrm{CI})$ complexes [13]. The magnetic data for the cobalt(II) complexes is consistent with the presence of a low-spin metal center. Low-spin $\mathrm{d}^{7}$ is expected to exhibit a large Jahn-Teller effect in six-coordinate complexes and such compounds are relatively rare. We propose that the green complexes we have isolated are five-coordinate in the solid state with the axial site occupied by the coordinating anion. The red-purple tetrafluoroborate salt probably contains a square planar cation. We believe that common solution species are formed in which other ancilliary ligands or solvent molecules may occupy the axial site. The compounds have limited solubility, and we have not been able to obtain consistent solution conductivity measurements. Solid state E.S.R. spectra of the complexes were not well-resolved.

The E.S.R. spectrum at $77 \mathrm{~K}$ of a green frozen methanolic solution of $\left\{\mathrm{CoL}\left(\mathrm{NO}_{3}\right)_{2} \cdot \mathrm{H}_{2} \mathrm{O}\right\}$ prepared and maintained under a dinitrogen atmosphere is shown in Figure 1a. This spectrum exhibits two anisotropic $\mathrm{g}$ values and is typical of a d $\mathrm{d}^{7}$ low-spin cobalt(II) complex. The parallel $\left(\mathrm{g}_{/ /}=2.028\right)$ and perpendicular $\left(\mathrm{g}_{\perp}=2.307\right)$ components are both well-resolved, and the perpendicular component clearly exhibits hyperfine coupling to the ${ }^{59}$ Co nucleus $(I=7 / 2$, 
$A=100$ G). The E.S.R. spectrum of a green frozen solution of the same complex in DMF is shown in Figure lb, and very closely resembles that of the methanolic solution $\left(\mathrm{g}_{/ /}=2.034, \mathrm{~g}_{\perp}=2.307, \mathrm{~A}=100 \mathrm{G}\right)$. This suggests that the solution species is grossly similar in each case. These spectra are similar to those previously reported for $[\mathrm{Co}($ acacen $)(\mathrm{py})]$ (py pyridine) in general shape and hyperfine coupling $(\mathrm{A}=80-100 \mathrm{G})[18]$.

Treatment of the methanolic and DMF solutions of $\left\{\mathrm{CoL}\left(\mathrm{NO}_{3}\right)_{2} \cdot \mathrm{H}_{2} \mathrm{O}\right\}$ with dioxygen resulted in slightly different qualitative behaviour. Upon bubbling dioxygen through a methanolic solution, a slight brownish tint developed. The E.S.R. spectrum of a frozen methanolic solution at $77 \mathrm{~K}$ which had been pretreated with dioxygen very closely resembles that of a methanolic solution of the starting complex, as seen in Figure la. Quantitative studies revealed that the development of the brown tint was associated with decreases in signal intensity, but no new features were observed in the E.S.R. spectrum. In contrast, bubbling dioxygen through a green solution of $\left\{\mathrm{CoL}\left(\mathrm{NO}_{3}\right)_{2} \cdot \mathrm{H}_{2} \mathrm{O}\right)$ in DMF resulted in a rapid change in colour of the solution to red-brown. The E.S.R spectrum of this red-brown solution (frozen glass, $77 \mathrm{~K}$ ) is shown in Figure 1c. The change from green to red-brown upon passing dioxygen through the DMF solution is associated with the formation of an E.S.R-silent solution species. This is compatible with the conversion of the lowspin $\mathrm{d}^{7}$ cobalt(II) complex to a low-spin $\mathrm{d}^{6}$ cobalt(III) species. The cobalt(III) center could be directly coordinated to a diamagnetic oxygen reduction product (oxo or peroxo) or there might be no direct Co-O interactions in the diamagnetic species. These observations are indicative of a process in which the interaction with dioxygen is facilitated by the presence of a strongly ligating solvent such as DMF, with the reaction in methanol being slow and incomplete. These observations parallel those previously reported for the interaction of $[\mathrm{Co}(\mathrm{salen})]$ with dioxygen $[8,9]$.

(a)

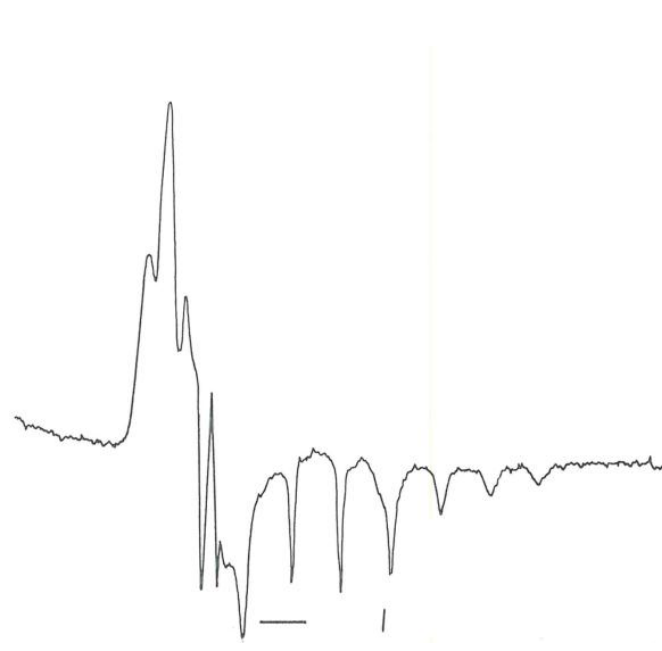

(b)

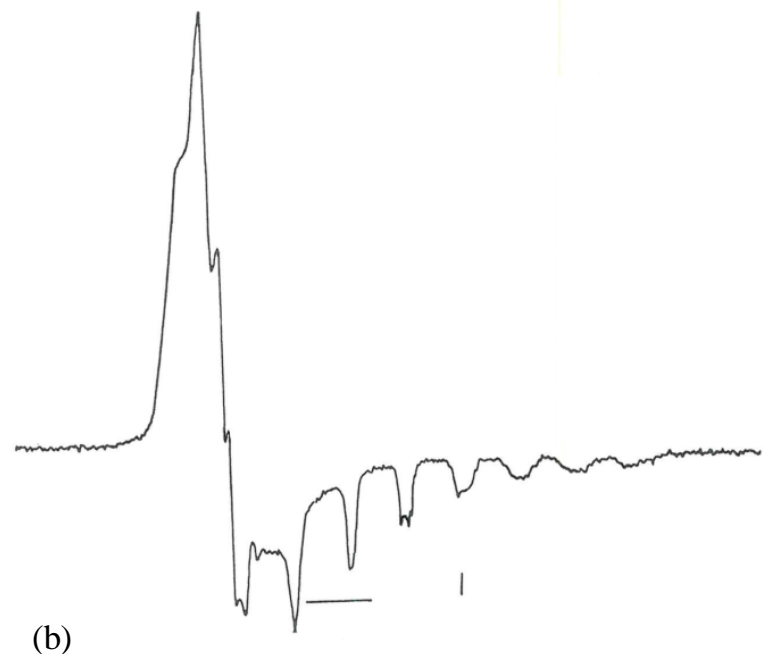

।

(c)

Figure 1. (a) E.S.R. spectrum of a green frozen methanol solution of $\left\{\mathrm{CoL}\left(\mathrm{NO}_{3}\right)_{2} \cdot \mathrm{H}_{2} \mathrm{O}\right\}$ at $77 \mathrm{~K}$ (b) E.S.R. spectrum of a green frozen DMF solution of $\left\{\mathrm{CoL}\left(\mathrm{NO}_{3}\right)_{2} \cdot \mathrm{H}_{2} \mathrm{O}\right\}$ at $77 \mathrm{~K}$ and (c) E.S.R. spectrum of a red-brown frozen DMF solution of $\left\{\mathrm{CoL}\left(\mathrm{NO}_{3}\right)_{2} \cdot \mathrm{H}_{2} \mathrm{O}\right\}$ at $77 \mathrm{~K}$ after exposure to dioxygen.

When dinitrogen was bubbled through the red-brown DMF solution which had been obtained after oxygenation, these colour changes were reversed and a green solution was obtained. Methanolic solutions showed a similar behavior. The E.S.R. spectra of the frozen green solutions in methanol or DMF obtained after flushing with dinitrogen were identical in all respects to those of the original solutions before oxygenation. This is strongly indicative of a reversible interaction with dioxygen. Behaviour of this type is associated with species in which the E.S.R.-silent product retains Co-O interactions. This is a strong supporting evidence for the formation of a cobalt(III) peroxo complex upon reaction with dioxygen (Figure 2). The overall similarity of behaviour to that reported for [Co(salen)] and related species suggests that the likely product is a binuclear peroxo-bridged dicobalt(III) complex.

The oxygenation-deoxygenation cycle may be repeated a number of times, although some gross decomposition eventually occurs. The deoxygenation may also be effected by evacuating the DMF or methanolic solutions. Solutions of $\left\{\mathrm{CoLI}_{2} \cdot \mathrm{H}_{2} \mathrm{O}\right\}$ in methanol or DMF exhibited similar colour changes upon reaction with dioxygen, and E.S.R. spectroscopy indicated that the presence of the coordinating iodide ion facilitated dioxygen binding in methanolic solution. The passage of dioxygen through boiling methanolic solutions of $\left\{\mathrm{CoLI}_{2} \cdot \mathrm{H}_{2} \mathrm{O}\right\}$ resulted in a color change from green to red, and upon concentration of this solution a red crystalline product formulated as $\{\mathrm{LCo}(\mu-$ $\left.\mathrm{O}_{2}\right) \mathrm{CoLI}_{4} \cdot 6 \mathrm{H}_{2} \mathrm{O}$ \} was obtained. This complex was diamagnetic and DMF solutions were E.S.R.-silent. Oxygen uptake experiments upon DMF solutions of $\left\{\mathrm{CoL}\left(\mathrm{NO}_{3}\right)_{2} \cdot \mathrm{H}_{2} \mathrm{O}\right\}$ confirmed a stoichiometry for the reaction of $0.5 \mathrm{O}_{2}: 1 \mathrm{Co}$. The data is consistent with the formation of a dicobalt(III) peroxo-bridged complex as shown in Figure 2. 


\section{DIOXYGEN BINDING BY COBALT(II) COMPLEXES}

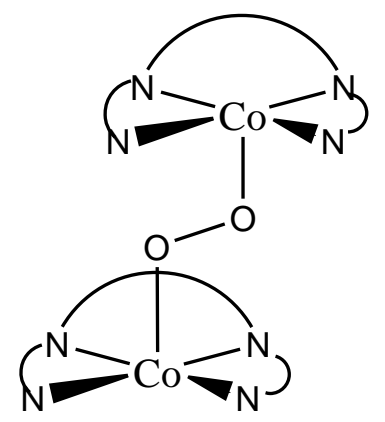

Figure 2. Proposed structure for the dicobalt(III) peroxo complex.

It is known that the binding of dioxygen to iron and cobalt complexes may be modified by or dependent upon the presence of other ligands in the solution, and we have investigated the behavior of $\left\{\mathrm{CoL}\left(\mathrm{NO}_{3}\right)_{2} \cdot \mathrm{H}_{2} \mathrm{O}\right\}$ solutions in the presence of ancillary ligands. The addition of a few drops of pyridine (py) to a DMF solution of $\left\{\mathrm{CoL}\left(\mathrm{NO}_{3}\right)_{2} \cdot \mathrm{H}_{2} \mathrm{O}\right\}$ yields a green solution; the E.S.R. spectrum at $77 \mathrm{~K}$ of a frozen DMF solution of $\left\{\mathrm{CoL}\left(\mathrm{NO}_{3}\right)_{2} \cdot \mathrm{H}_{2} \mathrm{O}\right\}$ containing pyridine is shown in Figure 3a. The spectrum is well-resolved and it is apparent that there are differences from the E.S.R. spectrum in the absence of pyridine. The parallel $\left(\mathrm{g}_{11}=2.087\right)$ and perpendicular $\left(\mathrm{g}_{\perp}=2.379\right)$ components are slightly shifted with respect to the spectrum in the absence of pyridine. Furthermore, some of the lines in the parallel part of the spectrum exhibit additional hyperfine coupling to ${ }^{14} \mathrm{~N}(I=1, \mathrm{~A}=11 \mathrm{G})$ and the coupling to ${ }^{59} \mathrm{Co}$ is reduced $(\mathrm{A}=80 \mathrm{G})$. These observations are compatible with the formation of a pyridine adduct in which one pyridine is coordinated to an axial site lying above the square plane described by the four nitrogen donors of the ligand L. This compound could be a five-coordinate square-based pyramidal species (Figure 4a, A = py) or an octahedral ion with solvent occupying the remaining octahedral site (Figure $4 \mathrm{~b}, \mathrm{~A}=\mathrm{py}$ ). Both of these structures are compatible with the reduction of the hyperfine coupling to the cobalt, as observed for complexes with $\mathrm{H}_{2} \mathrm{~L}^{2}$ or $\mathrm{H}_{2} \mathrm{~L}^{3}$ [18].

(a)

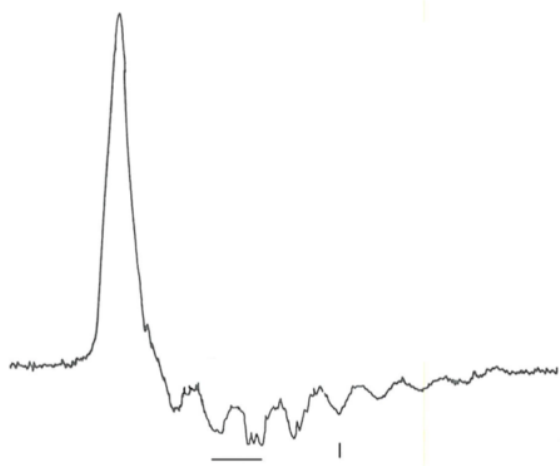

(b)

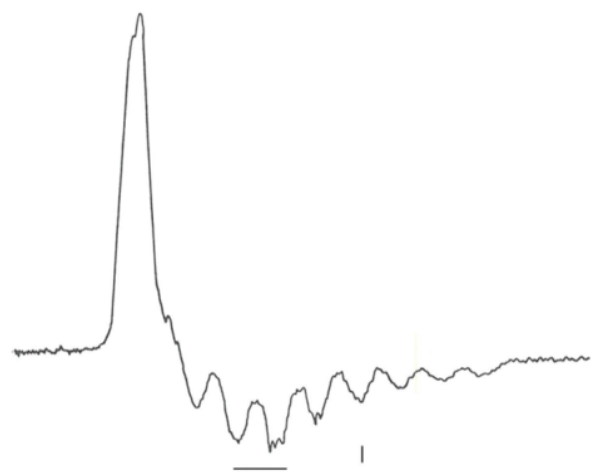

Figure 3. (a) E.S.R. spectrum of a green frozen DMF solution of $\left\{\mathrm{CoL}\left(\mathrm{NO}_{3}\right)_{2} \cdot \mathrm{H}_{2} \mathrm{O}\right\}$ containing pyridine at $77 \mathrm{~K}$. (b) E.S.R. spectrum of a green frozen DMF solution of $\left\{\mathrm{CoL}\left(\mathrm{NO}_{3}\right)_{2} \cdot \mathrm{H}_{2} \mathrm{O}\right\}$ containing 2-methylimidazole at $77 \mathrm{~K}$.

Upon exposure of DMF solution of $\left\{\mathrm{CoL}\left(\mathrm{NO}_{3}\right)_{2} \cdot \mathrm{H}_{2} \mathrm{O}\right\}$ containing pyridine to dioxygen, a red-brown solution was obtained. Once again, this frozen red-brown solution was E.S.R-silent at $77 \mathrm{~K}$, suggesting that a similar peroxobridged dicobalt(III) complex was formed. The red-brown compound was reconvened to the green E.S.R-active species upon bubbling dinitrogen through the solution. This process of oxygenation-deoxygenation could be repeated five times with no noticeable decomposition and no changes in the intensity or the character of the E.S.R. spectrum of the green species.

Very similar behavior was observed upon the addition of 2-methylimidazole (Meim) to a DMF solution of $\left\{\mathrm{CoL}\left(\mathrm{NO}_{3}\right)_{2} \cdot \mathrm{H}_{2} \mathrm{O}\right\}$. The E.S.R. spectrum at $77 \mathrm{~K}$ of a frozen solution containing 2-methylimidazole is shown in Figure $3 \mathrm{~b}$. The changes in the spectrum are similar to those seen upon the addition of pyridine $\left(\mathrm{g}_{11}=2.034, \mathrm{~g}_{\perp}=2.313, \mathrm{~A}_{\mathrm{Co}}=\right.$ $70 \mathrm{G}, \mathrm{A}_{\mathrm{N}}=16 \mathrm{G}$ ), suggesting the formation of an axially substituted complex (Figure $4 \mathrm{a}$ or $4 \mathrm{~b}, \mathrm{~A}=\mathrm{Meim}$ ). This green solution also reacted reversibly with dioxygen to yield an E.S.R.-silent red solution.

The resemblances between the behavior of the cobalt(II) complexes with $\mathrm{L}$ and those with $\mathrm{H}_{2}$ salen and related ligands are remarkable. In the presence of ancillary ligands such as pyridine, the [Co(salen)] system also changes its dioxygen binding behaviour to yield 1:1 superoxo adducts.

We have investigated the effect of solvent upon the reactions of 1:1 cobalt(II) complexes of $\mathrm{L}$ with dioxygen. The compounds $\left\{\mathrm{CoL}\left(\mathrm{NO}_{3}\right)_{2} \cdot \mathrm{H}_{2} \mathrm{O}\right\},\left\{\mathrm{CoLI}_{2} \cdot \mathrm{H}_{2} \mathrm{O}\right\}$ or $\left\{\mathrm{CoL}(\mathrm{SCN})_{2} \cdot \mathrm{H}_{2} \mathrm{O}\right\}$ are not significantly soluble in solvents other than water, methanol or DMF. The reaction of $\mathrm{L}$ with methanolic solutions of cobalt(II) tetrafluoroborate in the absence of dioxygen results in the formation of deep red-purple solutions. Concentration of these solutions in anaerobic conditions 
allows the isolation of a deep red-purple coloured crystalline complex formulated as $\left\{\mathrm{CoL}\left(\mathrm{BF}_{4}\right)_{2} \cdot \mathrm{H}_{2} \mathrm{O}\right\}$. This material is very air-sensitive in solution, but is moderately stable in the solid state. We have repeatedly attempted to obtain $\mathrm{X}$ ray quality crystals of this product; the recrystallization of the complex by the diffusion of diethyl ether vapour into an acetonitrile solution of $\left\{\mathrm{CoL}\left(\mathrm{BF}_{4}\right)_{2} \cdot \mathrm{H}_{2} \mathrm{O}\right\}$ results in the formation of beautiful red-purple needles. These needles lose solvent immediately when they are removed from the mother liquor, and we have been unable to mount $\mathrm{X}$-ray quality crystals. The E.S.R. spectrum at $77 \mathrm{~K}$ of a frozen solution of $\left\{\mathrm{CoL}\left(\mathrm{BF}_{4}\right)_{2} \cdot \mathrm{H}_{2} \mathrm{O}\right\}$ in DMF is identical to that of a DMF solution of $\left\{\mathrm{CoL}\left(\mathrm{NO}_{3}\right)_{2} \cdot \mathrm{H}_{2} \mathrm{O}\right\}\left(\mathrm{g}_{11}=2.034, \mathrm{~g}_{\perp}=2.310\right)$. The E.S.R. spectrum at $77 \mathrm{~K}$ of a frozen solution of $\left\{\mathrm{CoL}\left(\mathrm{NO}_{3}\right)_{2} \cdot \mathrm{H}_{2} \mathrm{O}\right\}$ in acetonitrile is shown in Figure 5; the spectrum qualitatively resembles that of the DMF solution, although the hyperfine coupling to ${ }^{59} \mathrm{Co}$ is not so well-resolved. These observations are indicative of similar solution species in DMF for $\left\{\mathrm{CoL}\left(\mathrm{BF}_{4}\right)_{2} \cdot \mathrm{H}_{2} \mathrm{O}\right\}$ and $\left\{\mathrm{CoL}\left(\mathrm{NO}_{3}\right)_{2} \cdot \mathrm{H}_{2} \mathrm{O}\right\}$ and of similar solution species in DMF and acetonitrile for $\left\{\mathrm{CoL}\left(\mathrm{BF}_{4}\right)_{2} \cdot \mathrm{H}_{2} \mathrm{O}\right\}$. Both DMF and acetonitrile solutions of $\left\{\mathrm{CoL}\left(\mathrm{BF}_{4}\right)_{2} \cdot \mathrm{H}_{2} \mathrm{O}\right\}$ react reversibly with dioxygen to generate E.S.R.-silent oxidation products.

(a)

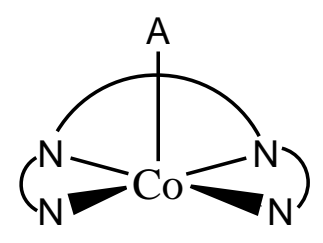

(b)

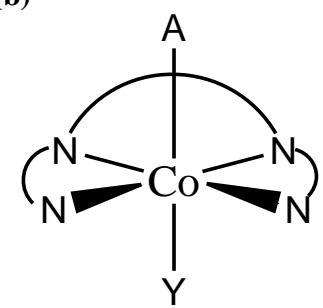

Figure 4. (a) Proposed structures for the complexes with ancillary ligand: A = py or Meim (b) Proposed structures for the complexes with ancillary ligand A and a coordinating solvent $\mathrm{Y}$.

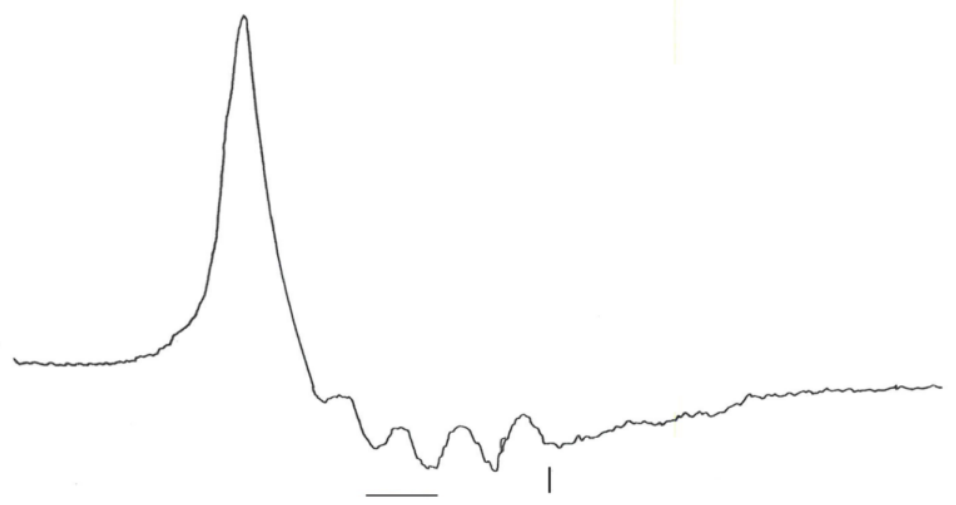

Figure 5. E.S.R. spectrum of a frozen acetonitrile solution of $\left\{\mathrm{CoL}\left(\mathrm{NO}_{3}\right)_{2} \cdot \mathrm{H}_{2} \mathrm{O}\right\}$ at $77 \mathrm{~K}$.

In contrast to the behavior of $\left\{\mathrm{CoL}\left(\mathrm{BF}_{4}\right)_{2} \cdot \mathrm{H}_{2} \mathrm{O}\right\}$ solutions discussed above, very different behavior was observed for acetonitrile solutions in the presence of ancillary ligands. Acetonitrile solutions of $\left\{\mathrm{CoL}\left(\mathrm{BF}_{4}\right)_{2} \cdot \mathrm{H}_{2} \mathrm{O}\right\}$ containing pyridine react with dioxygen to produce orange solutions, which are E.S.R-active. The E.S.R. spectrum at $77 \mathrm{~K}$ of such a frozen solution is shown in Figure 6. Once again an anisotropic spectrum is observed $\left(\mathrm{g}_{\perp}=2.009, \mathrm{~g}_{11}=2.067\right)$, and a much reduced hyperfine coupling constant to cobalt is seen $(A=10 \mathrm{G})$. This is compatible with a structure in which the unpaired spin density is significantly localized upon some other nucleus, and is suggestive of a cobalt(III) superoxide complex in which the spin density is essentially on oxygen (Figure 7). Very similar results were obtained with solutions of $\left\{\mathrm{CoL}\left(\mathrm{BF}_{4}\right)_{2} \cdot \mathrm{H}_{2} \mathrm{O}\right\}$ in neat pyridine. Once again, the reaction with dioxygen was to some extent reversible, and at least four oxygenation-deoxygenation cycles were possible without any detectable decomposition of the complex. Gas uptake experiments confirmed a stoichiometry for the reaction of $1 \mathrm{O}_{2}: 1 \mathrm{Co}$. 


\section{DIOXYGEN BINDING BY COBALT(II) COMPLEXES}

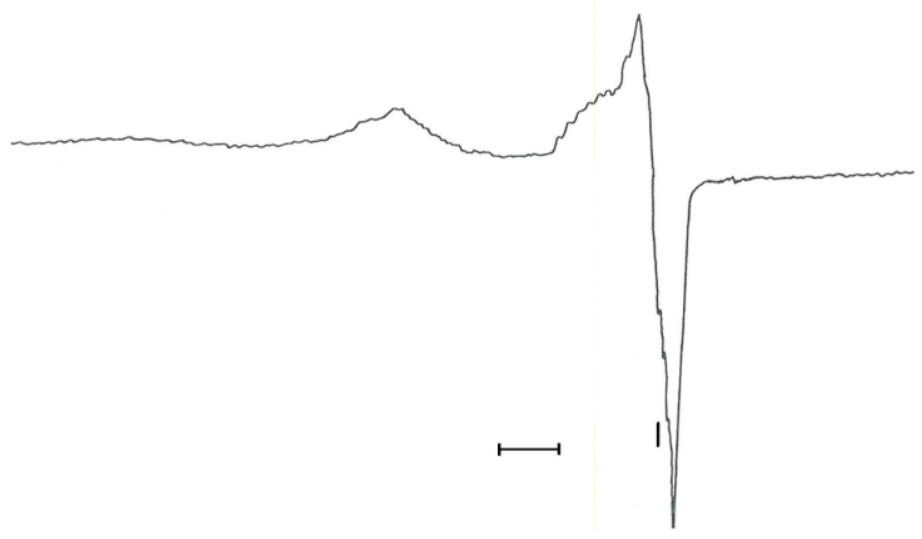

Figure 6. E.S.R. spectrum of an orange frozen DMF solution of $\left\{\mathrm{CoL}\left(\mathrm{BF}_{4}\right)_{2} \cdot \mathrm{H}_{2} \mathrm{O}\right\}$ containing pyridine at $77 \mathrm{~K}$ after exposure to dioxygen.

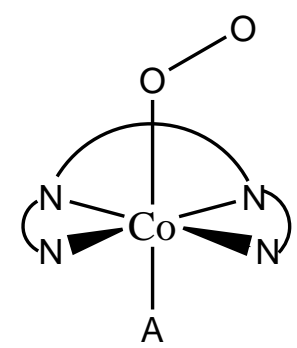

Figure 7. Proposed structure for the cobalt(III) superoxo complex with ancillary ligand A = py or Meim.

We have made a preliminary assessment of the use of these dioxygen complexes as oxygen carrier oxidation catalysts. The addition of an excess of triphenylphosphine to a red-brown solution obtained by the passage of dixoygen through a methanolic solution of $\left\{\mathrm{CoLI}_{2} \cdot \mathrm{H}_{2} \mathrm{O}\right\}$ resulted in the formation of a brown-green solution. Thin layer chromatography (TLC) of the solution indicated the formation of some triphenylphosphine oxide. The solution was stirred at room temperature under an atmosphere of dioxgen for 2 hours, after which period TLC analysis indicated the complete conversion of triphenylphosphine to triphenylphosphine oxide. The product triphenylphosphine oxide could be isolated from the solution in $95 \%$ yield. Amounts of phosphine up to ten times the weight of cobalt complex could be oxidized with no detectable loss of activity. The passage of dioxygen through DMF solutions of the red compound $\left\{\mathrm{LCo}\left(\mu-\mathrm{O}_{2}\right) \mathrm{CoLI}_{4} \cdot 6 \mathrm{H}_{2} \mathrm{O}\right\}$ containing triphenylphosphine also resulted in the formation of triphenylphosphine oxide. In both cases, the rate of oxidation of triphenylphosphine was considerably faster than that observed in the absence of the cobalt complex. We have not further investigated the mechanism of this reaction, which could proceed by direct reaction of the phosphine with the peroxo-bridged compound.

These cobalt complexes are also active in the oxidation of 2,6-bis $\left({ }^{t}\right.$-butyl)phenol. When DMF solutions of any of the complexes were stirred with 2,6-bis $\left({ }^{t}\right.$-butyl) phenol under dioxygen, TLC analysis indicated the disappearance of 2,6-bis $\left({ }^{t}\right.$-butyl $)$ phenol and the formation of two new products. Upon standing, dark red crystals of tetra $\left({ }^{t}\right.$-butyl $)$ diphenoquinone separated, which were characterized by mass, infrared and ${ }^{1}$ H N.M.R. spectroscopy. The other product of the reaction was similarly identified as 2,6-bis $\left({ }^{t}\right.$-butyl)quinone. Once again, only catalytic quantities of the cobalt complexes were required for the oxidation of the phenol, and total yields of the two oxidation products were in excess of $90 \%$. In general it was found that the product distribution was 6:4 2,6-bis $\left({ }^{t}\right.$-butyl)quinone:tetra( ${ }^{t}-$ butyl)diphenoquinone.

\section{Conclusion}

The $\mathrm{Co}(\mathrm{II})$ complexes $\mathrm{CoLX}_{2}$ based on $\mathrm{L}=8,8^{\prime}$-bis(aminomethyl)-2,2'-biquinoline and $\mathrm{X}=\mathrm{SCN}^{-}, \mathrm{BF}_{4}^{-}, \mathrm{I}^{-}$or $\mathrm{NO}_{3}^{-}$, have confirmed their oxygen-binding tendency in DMF solution. A dicobalt(III) peroxo-bridged complex is formed, associated with the formation of an E.S.R.-silent solution compatible with the formation of a low-spin $\mathrm{d}^{6}$ $\mathrm{Co}$ (III) species. The introduction of ancillary ligands such as pyridine and 2-methylimidazole into the Co(II) complex has enhanced their oxygen-binding tendency in solution. An axially substituted mononuclear complex has formed to yield an E.S.R.-silent solution typical for low-spin $\mathrm{d}^{6} \mathrm{Co}$ (III) species. 


\section{MUHAMMAD S. KHAN ET AL}

\section{Acknowledgement}

One of the authors (M.S.K.) acknowledges Sultan Qaboos University for a Research Grant (IG/SCI/CHEM/13/01) and for a research leave.

\section{References}

1. Murray, L.J., Dinca, M., Yano, J., Chavan, S., Bordiga, S., Brown, C.M. and Long, J.R. Highly-selective and reversible $\mathrm{O}_{2}$ binding in $\mathrm{Cr}_{3}(1,3,5 \text {-benzenetricarboxylate) })_{2}$. J. Am. Chem. Soc., 2010, 132(23), 7856-7857.

2. Sun, Y., Chen, K., Jia, L. and Li, H. Toward understanding macrocycle specificity of iron on the dioxygenbinding ability: a theoretical study. Phys. Chem. Chem. Phys., 2011, 13(30), 13800-13808.

3. Henrici-Olivé, G. and Olive, S. Activation of molecular oxygen. Angew. Chem. Int. Ed., 1974, 13(1), 29-38.

4. Sheldon, R.A. and Kochi, J.K., Chapter 4, Activation of Molecular Oxygen by Metal Complexes, In Metalcatalyzed Oxidations of Organic Compounds, p 71-119, ISBN 9780126393804, Academic Press, New York,1981.

5. Sheldon, R.A., Metal-catalyzed Oxidations of Organic Compounds: Mechanistic Principles and Synthetic Methodology including Biochemical Processes. Elsevier, 2012.

6. Buckingham, D.A., and Clark, C.R. In Comprehensive Coordination Chemistry, (Eds.) Wilkinson, G., Gillard, R.D. and McCleverty, J.A. Pergamon Press, Oxford, p 749-750, 1987.

7. Tiné, M.R. Cobalt complexes in aqueous solutions as dioxygen carriers. Coord. Chem. Rev., 2012, 256(1), 316327.

8. Shahabadi, N., Kashanian, S. and Darabi, F. DNA binding and DNA cleavage studies of a water soluble cobalt(II) complex containing dinitrogen Schiff base ligand: The effect of metal on the mode of binding. Euro. J. Med. Chem., 2010, 45(9), 4239-4245.

9. Calligaris, M., Nardin, G., Randaccio, L. and Ripamonti, A. Structural aspects of the synthetic oxygen-carrier NN'-ethylenebis-(salicylideneiminato) cobalt(II): structure of the addition compound with oxygen containing dimethylformamide. J. Chem. Soc. A: Inorg., Phys., Theo., 1970, 1069-1074.

10. Floriani, C. and Calderazzo, F. Oxygen adducts of Schiff's base complexes of cobalt prepared in solution. $J$. Chem. Soc. A: Inorg., Phys., Theo., 1969, 946-953.

11. Coleman, W.M. and Taylor, L.T. Dioxygen reactivity-structure correlations in manganese(II) complexes. Coord. Chem. Rev., 1980, 32(1), 1-31.

12. Crumbliss, A.L. and Basolo, F. Monomeric cobalt-oxygen complexes. Science, 1969, 164(3884), 1168-1170.

13. Calligaris, M., Nardin, G., Randaccio, L. and Tauzher, G. The structure of the 1:1 addition compound of molecular oxygen with $\mathrm{NN}^{\prime}$-ethylenebis(acetylacetoneiminato) cobalt(II) monopyridinate, Inorg. Nuc. Chem. Lett., 1973, 9(4), 419-422.

14. Rodley, G.A. and Robinson, W.T. Structure of a monomeric oxygen-carrying complex, Nature, 1972, 235, 438.

15. Chung, L.Y., Constable, E.C., Lewis, J., Raithby, P.R. and Kaye, P.T. Transition metal complexes of substituted $2,2^{\prime}$-biquinolines. Part 1 . The crystal and molecular structures of $\left[8,8^{\prime}\right.$-bis(aminomethyl)-2,2'-biquinoline $]$ dichloromanganese(II) and [8,8'-bis(aminomethyl)-2,2'-biquinoline] chlorocopper(II) chloride. J. Chem. Soc. Dalton Trans., 1988, (8), 2121-2125.

16. McGarvey, B.R. and Carlin, R.L. Transition Metal Chemistry. Vol. 3, Marcel Dekker, New York, p 129-130.

17. Figgis, B.N. and Lewis, J. The magnetic properties of transition metal complexes, Prog. Inorg. Chem., 1964, 6, $37-239$.

18. Hoffman, B.M., Diemente, D.L. and Basolo, F. Electron paramagnetic resonance studies of some cobalt(II) Schiff base compounds and their monomeric oxygen adducts. J. Am. Chem. Soc., 1970, 92(1), 61-65. 